\title{
METABOLIC EFFECTS OF EARLY PROTEIN UNDERNOURISHMENT AND RENOURISHMENT IN WISTAR RATS
}

\author{
EFEITOS METABÓLICOS DA SUBNUTRIÇÃO PROTEICA PRÉ-NATAL E \\ RENUTRIÇÃO EM RATOS WISTAR
}

\section{Josemberg da Silva BAPTISTA ${ }^{1,2}$; Marcelo Arthur CAVALLI' ${ }^{2}$, Lucilene Ferreira LUIZ ${ }^{2}$; Diana de Oliveira VONO ${ }^{2}$; Carlos Eduardo SEYFERT ${ }^{2,3}$; Sílvia de Campo BOLDRINI ${ }^{2,4}$; Edson Aparecido LIBERTI ${ }^{2}$}

1. Laboratory of Studies in Applied Morphology (LEMA), Department of Morphology, Federal University of Espirito Santo, Vitoria, ES, Brazil. josemberg.baptista@ufes.br; 2. Laboratory of Functional Anatomy Applied to Clinical and Surgery (LAFACC), Department of Anatomy, Biomedical Science Institute, University of São Paulo, São Paulo, SP, Brazil; 3. Department of Morphology, Federal University of Santa Maria; 4. (In memoriam)

\begin{abstract}
Malnutrition remains an important public health condition by affecting mostly children. The present study aimed to examine the effects of prenatal protein undernourishment and postnatal renourishment on the metabolism of pre-adult animals. Forty-five male Wistar rats originating from different litters were used. The Nourished $(\mathrm{N}, \mathrm{n}=15)$ and Undernourished $(\mathrm{U}, \mathrm{n}=30)$ groups were maintained on proteic and hypoproteic diets $(20 \%$ and $5 \%$ casein, respectively) from the intrauterine phase until the end of the experiment. The Renourished group (R) contained 15 animals, randomly chosen from $\mathrm{U}$ group, that consumed the $\mathrm{N}$ diet beginning on day 21 (weaning). All groups were maintained until day 60. The experimental data was acquired daily for body weight, feed and water intake, feces and urine excretion. Data analysis was made with the total results and the ratio between them. The $\mathrm{U}$ group animals developed uniformly sparse hair late and experienced intense sweating, features that were not observed during the experiment in the $\mathrm{R}$ and $\mathrm{N}$ animals groups. The $\mathrm{R}$ group had the largest weight gain and feed and water intake ratio/weight at experimental period, followed by the $\mathrm{N}$ group animals. The final body weight and food intake decreased gradually in the order N-R-U, but none of the other parameters showed a statistical difference between the $\mathrm{N}$ and $\mathrm{R}$ animals. Compared to groups $\mathrm{N}$ and $\mathrm{R}$, the $\mathrm{U}$ group animals consumed $90 \%$ and $81 \%$ more food and water, respectively. Protein undernourishment induced metabolic dysfunction in the $\mathrm{U}$ group animals. The similarity in the experimental parameters of the $\mathrm{N}$ and $\mathrm{R}$ groups suggests that an early feeding correction was effective in reestablishing the organic functions of the $\mathrm{R}$ group animals.
\end{abstract}

KEYWORDS: Undernourishment. Refeeding. Metabolismo. Nourishment. Rats.

\section{INTRODUCTION}

Undernourishment is caused by an improper diet, either hypocaloric (marasmus) or hypoproteic (kwashiorkor), and can be determined by the poor absorption of nutrients or anorexia. This condition has been the focus of several studies since the early seventies, including those that used experimental models(ANTHONY; EDOZIEN, 1975), since it is one of the most important public health problems worldwide. It affects mainly the most susceptible age groups, such as infants and children, during critical developmental periods(MONTE, 2000).

The number of undernourished children in the world today surpasses 500 million. Moreover, more than half of the deaths in this population group are attributed to undernourishment. The other major causes of death are malaria, acute respiratory infections, diarrhea, tuberculosis and HIV/AIDS; however, these are often complicated by, or have a direct connection to, different degrees of undernourishment(NEUMANN; GEWA; BWIBO, 2004).
Due to the magnitude and the disastrous consequences on growth, development and survival, child undernourishment remains a major public health problem in the world today(MONTE, 2000). The delay in growth and development makes the body more susceptible to immune system deficiencies, infections and neuropsychomotor problems, as well as morphological, behavioral and cognitive changes(NUNES et al., 2002). The effect on growth, in particular, is a major focus of attention in children's health, with the anthropometric delay being a major factor in the epidemiological malnutrition data from Brazil and the world(ROMANI; LIRA, 2004; WATERLOW, 1997).

Several studies have been published on the effects of protein undernourishment and the role the renourishment plays in various organs and tissues(BAPTISTA JS et al., 2013; GREGGIO et al., 2010; LIBERTI et al., 2007; OLIVEIRA et al., 2010). However, the morphological and structural changes caused by this state of protein deprivation did not reveal or bring understanding to the 
metabolic aspects of the adopted experimental model.

Thus, although there is extensive literature describing pathological conditions in which undernourishment may be the precursor agent, there is a lack of strong and detailed data on the metabolic behavior exhibited with this disease from the systemic view of the organism, especially during renourishment of the individual, a fact that has not yet been addressed in the literature. Therefore, we propose to study the metabolic parameters of rats subjected to prenatal proteic undernourishment and postnatal renourishment during the pubertal stage of these animals.

\section{MATERIAL AND METHODS}

\section{Animals and experimental groups}

The present study was approved by the Ethics Committee on Animal Experimentation (CEEA, University of São Paulo-USP, number 31, sheet 44 , book 2). The experimental protocol was performed with adaptations from previously published work by our group(GREGGIO et al., 2010; LIBERTI et al., 2007; OLIVEIRA et al., 2010). Wistar rats (Rattus norvegicus) were used (23 males and 23 females, between 90 and $120 \mathrm{~d}$ of age with body masses between 280 and $320 \mathrm{~g}$ ), obtained from the animal colony of the Biomedical Science Institute, USP. These animals were mated for seven days in standard plastic cages in the vivarium of the Department of Anatomy, USP, in air-conditioned rooms with controlled temperature ( 23 to $25^{\circ} \mathrm{C}$ ) and $12 \mathrm{~h} \mathrm{light/dark} \mathrm{cycle.} \mathrm{During} \mathrm{the}$ experimental period, the animals received water and food ad libitum: proteic $(20 \%$ casein) for the nourished group ( $\mathrm{N} ; \mathrm{n}=8$ pairs), or hypoproteic (5\% casein) for the undernourished group (U; $n=15$ pairs). The diets were prepared by a specialized biochemical laboratory (Rhoster Industry and Trade LTD, Aracoiaba da Serra, SP, Brazil) according to the "American Institute of Nutrition" for the standardization of diets in laboratory animals(REEVES; NIELSEN; FAHEY, 1993).

After the confirmation of pregnancy, the females were separated into individual cages and continued to be fed their respective diets: $\mathrm{N}$ (8 females) and $U$ (15 females). These animals were monitored daily for the birth of new litters. To standardize the experiment, only litters with six pups from both groups were used. The adoption of this criterion ensured a lower discrepancy in the body mass of the obtained animals and the same stress level between mothers of both groups. Thus, the only variable experimental factor for this protocol was the type of diet.

The mothers were maintained on their respective diets until their cubs completed 21 days of extrauterine life, which was the determined weaning time. Two males from each litter were randomly assigned for experimental standardization, and the animals that were not selected were excluded from the study. In one of the litters of the $\mathrm{N}$ group, only one animal was chosen, so that the experiment was standardized to the number of animals. After this step, the following groups were formed:

- Nourished (N) - maintained on a proteic diet until 60 days of age $(n=15)$;

- Undernourished (U) - maintained on a hypoproteic diet until 60 days of age $(\mathrm{n}=15)$;

- Renourished (R) - formed by undernourished animals that were maintained on the hypoproteic diet until weaning after which they were maintained on the proteic diet until 60 days of age $(n=15)$.

\section{Acquisition of systemic metabolic data}

Group formation was followed by the experimental period (EP), during which the animals were divided in two types of monitoring protocols for the acquisition of metabolic parameters and the observance of differences between the monitoring models: 1) EP in the box (Bx): Five animals from each group $(\mathrm{N}, \mathrm{U}, \mathrm{R})$ were individually maintained in standard rectangular cages with a protective aluminum top grill, until the $60^{\text {th }}$ extrauterine day; 2) EP Metabolic (M): Ten animals from each group $(\mathrm{N}, \mathrm{U}, \mathrm{R})$ were individually maintained in metabolic cages (TECNIPLAST $\AA$, model 3700M081, Buguggiate, Italy) where the following parameters were measured daily at the same time: body weight, water intake, feed intake, urine and feces excretion. A precision balance was used (Marte AS1000C, Sao Paulo, Brazil) to weigh the collectors and repositories of food and feces. The cages remained in a specific room where the daily entrance was restricted to two caretakers who were properly dressed to handle the animals.

On the $60^{\text {th }}$ day, that corresponding to the pubertal stage of rats(VIAU et al., 2005), there were 15 animals in each group (10 metabolically monitored and 5 monitored in the boxes according to their diet) that were subjected to a final weighing and then euthanized.

\section{Analysis of metabolic data}

The adoption of this experimental methodology allowed for the acquisition of experimental data points, such as daily parameters 
or averages at the end of the experiment, mentioned above, as well as an analysis of the ratio between them. Thus, by analyzing the averages obtained throughout the EP, and combining two parameters, measurement can be done in percentages, the ratios of intake/body weight, feces/intake and urine/water consumption. The ratio of water/body weight was expressed by the unit $\mathrm{ml} / \mathrm{g}$.

For the purpose of daily acquisition of the common parameters, an investigation was conducted on the nutritional evolution of the animals on a temporal scale during the EP. Thus, the data used for effective comparisons and monitoring of the groups were combined after the $1^{\text {st }}$ day into periods of four days (i.e., $2^{\text {nd }}$ to $5^{\text {th }}$ day, etc.).

Body weight development of animals in the $\mathrm{N}$, U and R groups during the EP was obtained by the ratio between two weights established: weight number 1 was obtained when the animal (21 days postnatal) began the metabolic experiment; weight number 2 was obtained immediately before euthanasia (day 39 of the experiment).

\section{Statistical analysis}

The significance level was set at $95 \%$. For simple comparisons (between groups, for example) Student's $t$ test was used. For analyses comparing more than two factors (among three groups or parameters), we used the analysis of variance (ANOVA) with two factors, or with repeated measurements (for temporal analysis), in addition to Tukey's test to observe differences among the data.

\section{RESULTS}

\section{Assessment of Monitoring}

Using this experimental protocol with metabolic cage monitoring, no experimental obstacles were observed. Nevertheless, clinical differences were observed in animals from different groups. Surprisingly, mothers belonging to the $U$ group gave birth to more puppies, which in turn had delayed fur development, compared with the animals in the $\mathrm{N}$ group. In the Metabolic EP, the animals showed variable behavior, sometimes active and reactive. At times, these animals displayed hypoactive, lethargic behavior, a characteristic present in all groups. On several occasions, the animals of the $U$ group became enclosed in the feed storage container of the metabolic cage or, in the case of the animals monitored in the boxes, covered with wood shavings. Nevertheless, these animals had uniformly sparse fur, and were short and less healthy. These characteristics were not observed in the animals of the $\mathrm{N}$ group and, ultimately, in animals of the $\mathrm{R}$ group.

Some animals monitored in the metabolic cages, belonging to the $U$ group, showed intense sweating, evidenced by the apparent transpiration on the lid of the cage. In addition, these animals were at least two times smaller in length compared with the other groups. The animals in the $\mathrm{R}$ group presented with pasty feces at the beginning of the feed readaptation and were slightly smaller than those in the $\mathrm{N}$ group.

Although there was a decrease, in both monitoring methods, of the body weight in the following order: $\mathrm{N}-\mathrm{R}$ - U, when these values were compared within the groups monitored in the $\mathrm{Bx}$ and $M$ methods, no statistically significant differences were observed (Table 1). The animals of the $\mathrm{R}$ group were the most approached to the animals in the $\mathrm{N}$ group, though there was a significant decrease in their body mass. However, a drastic decrease related to this parameter occurred in the animals of the $\mathrm{U}$ group.

Table 1. Quantitative comparison between male Wistar rats on three dietary regimes monitored in boxes $(\mathrm{Bx})$ and in metabolic cages $(M)$. Values are means \pm SD.

\begin{tabular}{lccc}
\hline Parameters & Nourished & Undernourished & Renourished \\
\hline Body weight of M animals $(g)$ & $289.7 \pm 13.7$ & $58.6 \pm 18.6^{*}$ & $207.9 \pm 17.0^{*}$ \\
Body weight of Bx animals $(g)$ & $286.8 \pm 19.2$ & $61.6 \pm 12.5^{*}$ & $211.7 \pm 17 *$ \\
\hline & & & $*$ ANOVA; $p<0.05$
\end{tabular}

\section{Metabolic Assessment}

The measurement of daily feed intake, water intake, feces and urine elimination allowed to obtain metabolic parameters between groups (Table 2).
The data analysis showed similarities between groups $\mathrm{R}$ and $\mathrm{N}$, except for the feed intake, which showed a slightly significant difference between the two groups. Nevertheless, the observed parameters 
Table 2. Average of metabolic data on male Wistar rats under three dietary regimes from the $1^{\text {st }}$ to the $39^{\text {th }}$ day of monitoring. Values are means \pm SD.

\begin{tabular}{lcccc}
\hline Parameters & Nourished & Undernourished & Renourished & Results \\
\hline Feed intake $(g)$ & $15.5 \pm 0.7$ & $7.5 \pm 1.0^{*}$ & $13.1 \pm 1.3^{*}$ & $\mathrm{~N}>\mathrm{R}^{*}>\mathrm{U}^{*}$ \\
Water intake $(\mathrm{ml})$ & $25.9 \pm 2.1$ & $11.4 \pm 2.4^{*}$ & $20.8 \pm 4.7$ & $\mathrm{~N}=\mathrm{R}>\mathrm{U}^{*}$ \\
Urine excretion $(\mathrm{ml})$ & $15.9 \pm 2.4$ & $5.9 \pm 1.6^{*}$ & $12.5 \pm 3.1$ & $\mathrm{~N}=\mathrm{R}>\mathrm{U}^{*}$ \\
Feces excretion $(\mathrm{g})$ & $1.95 \pm 0.16$ & $0.98 \pm 0.26^{*}$ & $1.63 \pm 0.31$ & $\mathrm{~N}=\mathrm{R}>\mathrm{U}^{*}$ \\
\hline & & & \multicolumn{2}{c}{$*$ ANOVA $\mathrm{p}<0.05$}
\end{tabular}

In the temporal analysis based on the EP, the body mass gain in the $\mathrm{N}$ group differed significantly from day to day, while the U group only obtained statistical difference from the $8^{\text {th }}$ day. Animals in the $\mathrm{R}$ group also gained significant weight soon after the $2^{\text {nd }}$ day of the experiment, and from the $4^{\text {th }}$ day, this group showed a statistically significant difference compared with the animals in the $U$ group (Figure 1, p<0.05).

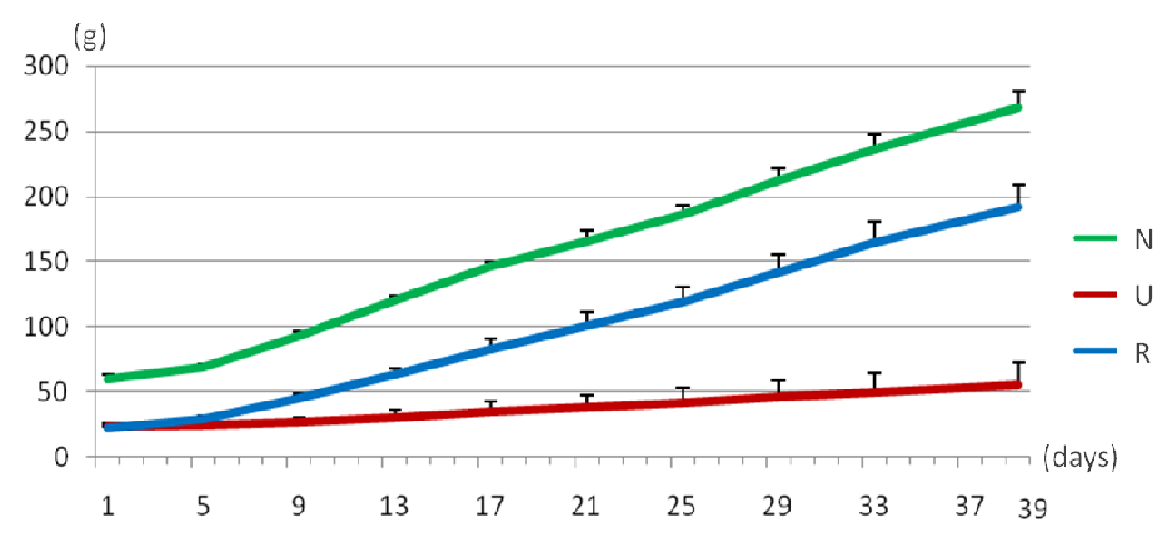

Figure 1. Timeline analysis of male Wistar rat weight gain under three dietary regimes. Values are means \pm SD. $\mathrm{N}$ = nourished; $\mathrm{U}=$ undernourished; $\mathrm{R}=$ renourished.

Food intake is significantly increased in the $\mathrm{N}$ animals starting from the $1^{\text {st }}$ day of the experiment until the $10^{\text {th }}$ day and, similarly, the $\mathrm{R}$ animals showed increased feed consumption from the $5^{\text {th }}$ day until the $14^{\text {th }}$ day, at which time both groups plateaued. The $\mathrm{U}$ showed significant feed intake from the $10^{\text {th }}$ day until the $29^{\text {th }}$ day, at which point there was a decrease in the intake. In the $1^{\text {st }}$ day of monitoring, all groups are statistically equal $(p>0.05)$. By the $2^{\text {nd }}$ day, statistical differences for feed intake can already be observed between animals in the $\mathrm{N}$ and $\mathrm{U}$ groups, while animals in the $\mathrm{R}$ group only differ from $\mathrm{U}$ animals starting on the $17^{\text {th }}$ day of the experiment (Figure $2-A, p<0.05$ ).

The $\mathrm{N}$ animals significantly increased their water intake daily from the $10^{\text {th }}$ to the $25^{\text {th }}$ day of monitoring and then plateaued. The animals of the $\mathrm{R}$ group significantly increased their water consumption from the $1^{\text {st }}$ to the $22^{\text {nd }}$ day of monitoring, and, similar to the $\mathrm{N}$ animals, then plateaued. Only after the $25^{\text {th }}$ day of monitoring did the animals in the $U$ group present a significant increase in water consumption. At first, the $\mathrm{N}$ and $\mathrm{U}$ animals did not differ in this parameter, and both were different from the $\mathrm{R}$ animals. However, by the $2^{\text {nd }}$ day the $\mathrm{R}$ group did not differ from the $\mathrm{N}$ animals, and, after the $14^{\text {th }}$ day, both the $\mathrm{R}$ and the $\mathrm{N}$ animals are statistically different from the $U$ group (Figure 2 - B, p<0.05).

The temporal observation of fecal excretion showed that $\mathrm{N}$ animals differed from the $\mathrm{U}$ animals only after the $18^{\text {th }}$ day of monitoring. From the $30^{\text {th }}$ 
day, all groups maintained statistically significant differences in a decreasing manner: N-R-U. Due to the technical limitations of the cage and/or due to soft feces of the animals, this assessment started from the $13^{\text {th }}$ day of the experiment. Prior to that day there was not enough data for a statistical analysis (Figure 2 - C).

Animals in the $\mathrm{N}$ group showed a significant increase in urine excretion from the $14^{\text {th }}$ day until the $26^{\text {th }}$ day, at which point the difference was no longer significant. The $\mathrm{U}$ animals showed slightly significant urine excretion from the $25^{\text {th }}$ to the $29^{\text {th }}$ day, after which there was no significant
BAPTISTA, J. S. et al.

difference. The $\mathrm{R}$ animals showed, from the beginning of the experiment, an increase in urine excretion ( $5^{\text {th }}$ day) up to the $22^{\text {nd }}$ day, at which point there was no longer any statistical significance. When comparing among the groups, the $\mathrm{N}$ animals excreted a statistically greater amount of urine than the $\mathrm{U}$ animals, while the $\mathrm{R}$ animals behaved similar to the $\mathrm{U}$ animals until the $13^{\text {th }}$ day, at which point their urine excretion became significantly greater than the $U$ animals $(p<0.05)$. Animals in the $R$ group excrete less urine than the $\mathrm{N}$ group until the $9^{\text {th }}$ day; after which time there is no significant difference (Figure 2 - D, p>0.05).
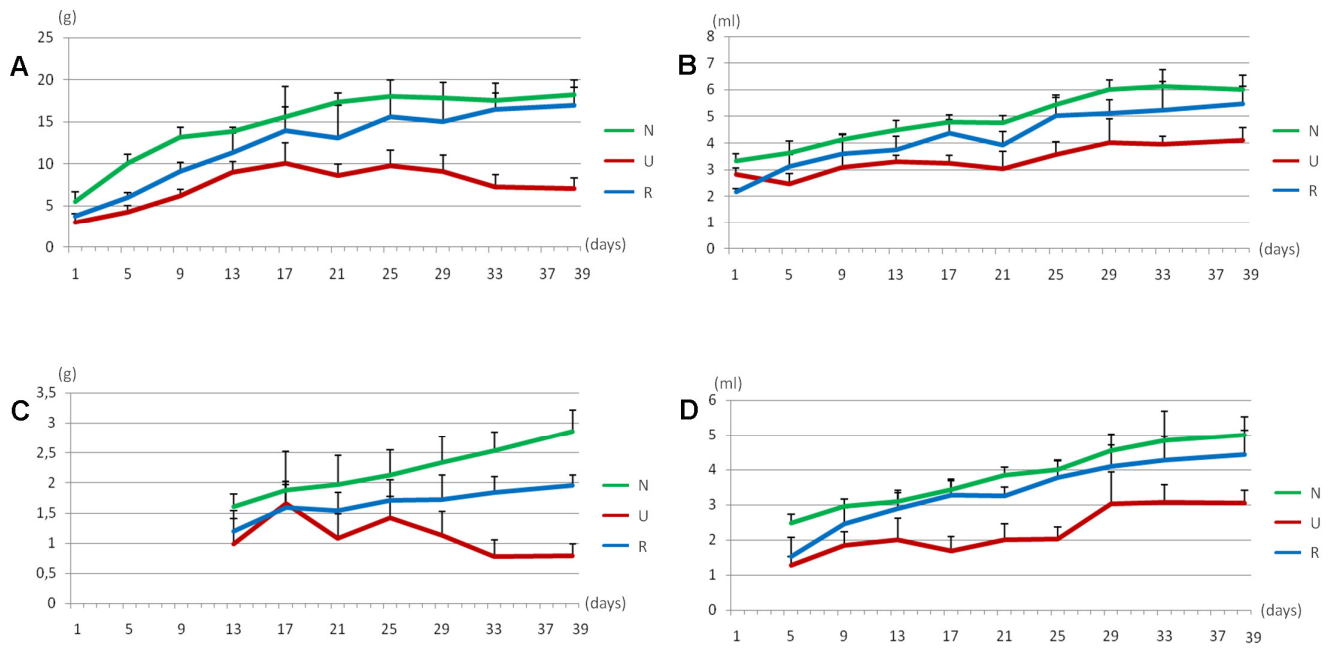

Figure 2. Timeline graph of feed intake (A), water intake (B), fecal (C) and urine excretion (D) of male Wistar rats under three dietary regimes. Values are means $\pm \mathrm{SD} . \mathrm{N}=$ nourished; $\mathrm{U}=$ undernourished; $\mathrm{R}=$ renourished.

When assessing the ratios of food intake/body weight and water/body weight, it was observed that the animals in the $U$ group had an elevated percentage, different from the other groups $(\mathrm{N}$ and $\mathrm{R}$ ) that did not differ statistically. In descriptive terms, animals in the $\mathrm{U}$ group consumed daily $21 \pm 4 \%$ of their weight in food and for each 1 $\mathrm{g}$ of their body weight these animals consumed the equivalent of $0.29 \pm 0.04 \mathrm{ml}$ of water daily. There was parity among the groups $(\mathrm{N}, \mathrm{U}$ and $\mathrm{R})$ in regards to the feces/intake ratio $(\%)$, while for the urine/water consumption ratio (\%), the $\mathrm{U}$ group showed a slight decrease, approximately $7.5 \%$, compared to the other groups, which was shown to be statistically significant (Table 3).

Table 3. Relationships among the metabolic means $( \pm$ SD) of male Wistar rats under three dietary regimes.

\begin{tabular}{lllll} 
Parameters & Nourished & Undernourished & Renourished & Results \\
\hline \% Intake/body weight & $10 \pm 0.2$ & $21 \pm 4^{*}$ & $14 \pm 1$ & $\mathrm{U}>\mathrm{R}=\mathrm{N}$ \\
\% Feces/intake & $12 \pm 0.8$ & $14 \pm 4$ & $11 \pm 1$ & $\mathrm{U}=\mathrm{R}=\mathrm{N}$ \\
Water/body weight (ml/g) & $0.16 \pm 0.01$ & $0.29 \pm 0.04^{*}$ & $0.21 \pm 0.04$ & $\mathrm{U}>\mathrm{R}=\mathrm{N}$ \\
\% Urine/water consumption & $60.0 \pm 3.4$ & $52.5 \pm 3.5^{*}$ & $59.9 \pm 3.9$ & $\mathrm{U}<\mathrm{R}=\mathrm{N}$
\end{tabular}

*ANOVA; $<<0.05$ 
Animals of the $\mathrm{R}$ group differed from the other animals with regards to body mass progression. Thus, as observed in Figure 1, there was a multiplication of body weight in these animals, on the average of $9.1 \mathrm{X}$, while in the animals of the $\mathrm{N}$ and $\mathrm{U}$ groups, this result was 4.7 and 2.4X, respectively. Thus, it was observed that animals of the $\mathrm{R}$ group grew, on average, $93.5 \%$ and $141 \%$ more than animals in the $\mathrm{N}$ and $\mathrm{U}$, respectively. The order of growth among the groups was $\mathrm{R}>\mathrm{N}>\mathrm{U}$ ( $\mathrm{p}<0.001$ between the groups).

\section{DISCUSSION}

It is known that protein or protein-calorie undernourishment affects different organs and systems by either direct (cellularity and function) or indirect (growth and organism development) involvement, both in humans and in well-controlled experimental models(BAPTISTA JS et al., 2013; BEDI, 1991; GOMES et al., 2006; MONTE, 2000). Understanding the metabolism of animals subjected to malnutrition elucidates many aspects of this complex syndrome, helping scientists and health professionals with reliable data on the evolutionary, functional and morphological impairments, and on recovery from the disease. Therefore, an experimental model that can be subjected to severe protein undernourishment is useful since protein undernourishment is the main type of malnutrition in developing countries (loss of essential structural amino acids) and given the range of carbohydraterich foods(MONTE, 2000; MONTEIRO, 2003; NEUMANN; GEWA; BWIBO, 2004).

Several authors have worked with similar experimental protocols to the one used in the present study; however, they used 42 day-old animals(CASTELUCCI et al., 2002; GOMES et al., 2006; GREGGIO et al., 2010; LIBERTI et al., 2007; OLIVEIRA et al., 2010). Since there are no indications in these studies of animals being monitored in the period evaluated (60 days), nor of any metabolic monitoring.

The present study used metabolic monitoring, which allowed the collection of accurate data on the metabolism of the experimental animals, suggesting that the protocol is appropriate for the intended research. The first goal was to monitor possible behavioral or body changes between animals that are monitored differently: alone (metabolic) or collective (boxes). It was important because the first limitation of the study was to keep animals naturally living in community in seclusion and provide some bias for the research. The non- statistical differences in body weight shows that these animals did not suffer in seclusion and it did not become a bias(DOMÍNGUEZGERPE; REY-MÉNDEZ, 2000).

Low body weight and growth retardation are the primary reported data in undernourishment animals or humans (MUGERWA, 1971; NUNES et al., 2002; ROMANI; LIRA, 2004; WATERLOW, 1997); when the malnutrition is imposed on the mother this affects especially the intrauterine phase(BRETON et al., 2009; COUPÉ et al., 2009). This data is confirmed in the experimental model used, which showed that undernourished animals had the lowest body weight, in addition to the lowest intake of food and water, and the lowest excretion of urine and feces.

Although the weight increased in the $R$ group animals, it was not sufficient to reach the level of the $\mathrm{N}$ group animals. In addition, the body length of the $\mathrm{R}$ animals did not approach those of the $\mathrm{N}$ animals, even with the long period of dietary change adopted (39 days). Similar findings were demonstrated in Wistar rats and in humans(CASTELUCCI et al., 2002; MONTE, 2000; NUNES et al., 2002). These observations have been attributed to changes in the cell proliferation of bone marrow precursors, which act in response to growth stimuli, causing a loss in development, precisely during the period in which the animal needs the most protein intake(NAKAJIMA et al., 2014).

In contrast, it was confirmed that undernourishment, based on the supply of the hypoproteic diet, led to disparate metabolic dysfunction in the animals of the $U$ group, demonstrated by the excessive food intake that was disproportionate to their weight. This was an attempt to satiate their protein need, and the percentage of intake/body weight was on average 90\% greater than that observed for the animals in the $\mathrm{N}$ and $\mathrm{R}$ groups. It is represents that Such results corroborate the work of Coupé and colleagues(COUPÉ et al., 2009), who showed that maternal nutrient restriction results in the appetite disturbance upon feeding recovery(DESAI; BABU; ROSS, 2007); however, metabolic data was not collected, so we cannot exactly compare results.

The metabolic imbalance triggers a massive release of endogenous corticosteroids via activation of the hypothalamic-pituitary-adrenal axis. This reaction originates from a hypothalamic stimulus of the adenohypophysis, resulting in the release of adrenocorticotropic hormones that, in the adrenal cortex, will release corticosteroids(DOMÍNGUEZGERPE; REY-MÉNDEZ, 2000; NAKAJIMA et al., 2014). These corticosteroids stimulate the use of 
metabolic tools, such as lipolysis and proteolysis, in an attempt to return to homeostasis. They constitute one of the maintainers of the system, and are widely considered the cause of low birth weight and height observed in these animals. In addition, another three hormones are involved in this process: leptin, growth hormone and ghrelin. Leptin is produced and released in amounts directly proportional to the mass of adipose tissue in the body, signaling to the hypothalamus the amount of stored energy, as well as the regulation of food intake and thermogenesis(SAVINO et al., 2007). Protein restriction causes an increase in serum growth hormone performing lipolysis, providing organism maintenance through fatty acids, aided by corticosteroids, which change the peripheral energy source(PIMSTONE et al., 1968). Thus, leptin secretion decreases since there is less adipose tissue in these animals, decreasing the feedback process to the hypothalamus that limits the feeling of hunger, allowing excess food intake by the animal without the feeling of satiation.

Ghrelin, which is a protein produced in the gastrointestinal tract, is important in signaling and regulating the energy balance. This molecule triggers a signaling cascade that stimulates the release of gastric enzymes and growth hormones, in addition to increasing adiposity and energy consumption in animals and humans. Thus, it is believed that the observed increase in appetite in the animals in the present study is derived from the increase in ghrelin production, to the detriment of other proteins that reduce energy consumption, such as bombesin, cholecystokinin and glucagon-like peptide(WERNETTE; WHITE; ZIZZA, 2011).

Interestingly, all groups showed the same feces/intake ratio (\%), which shows that there was no functional impairment of the gastrointestinal tract. These data were obtained through the morphoquantitative characterization of the myenteric plexus of undernourished rats(CASTELUCCI et al., 2002; GOMES et al., 2006; GREGGIO et al., 2010). Based on these studies and since the animals in the $U$ group suffered protein deprivation, it is possible that the digestive system of these animals did not exhibit severe changes. Instead the digestive system searches for ways to adapt to resist this injury and to absorb the maximum amount of nutrients: the data revealed that animals of the $\mathrm{R}$ group were similar, in regards to body weight, to the animals of the $\mathrm{N}$ group on the $2^{\text {nd }}$ day of the experiment, while on the $4^{\text {th }}$ day, their body mass gain was already significantly different from the body weight of the $U$ group. Furthermore, it can be suggested that, based on the parameters of water consumption and urine excretion, there was no functional impairment of the excretory system since animals of the $\mathrm{R}$ group showed data equivalent to those seen for the animals in the $\mathrm{N}$ group on the $2^{\text {nd }}$ and $6^{\text {th }}$ days, respectively. Thus, it can be asserted that the $\mathrm{R}$ animals, in most parameters, behaved like the $\mathrm{N}$ animals, and they do not exhibit the same parameters as the $U$ animals from the period between the $14^{\text {th }}$ and $17^{\text {th }}$ day of the $\mathrm{EP}$, while the $\mathrm{U}$ animals maintain or decrease in their parameters.

Likewise, the metabolic disarray and consequent excessive release of endogenous corticosteroids(DOMÍNGUEZ-GERPE; REYMÉNDEZ, 2000; NAKAJIMA et al., 2014) led to an $81 \%$ increase in the ratio of water intake/body weight of the $U$ animals, while the urine excretion/water consumption ratio was $12 \%$ lower compared to the other two groups. This allows to infer that the imbalanced of metabolism leads to higher consumption and use of water to satisfy their metabolic needs. It is possible that this "cumulative" water is retained in the tissue, probably due to low levels of plasma proteins; however, no swelling was observed in these animals.

Except for the final body weight and the final average feed intake, all other analyzed parameters were similar between the animals of the $\mathrm{R}$ group and the animals of the $\mathrm{N}$ group, thus suggesting effective nutritional reestablishment.

In conclusion, it was observed that the protein undernourishment used in the present research model caused severe metabolic dysfunction showed by the imbalanced of Intake/body weight, Feces/intake, Water/body weight, Urine/water consumption. However, administration of a normal protein diet during an early period to animals previously undernourished proved to be effective, suggesting normalization of the parameters related to metabolism since these results were similar to those found in the control animals.

\section{ACKNOWLEDGMENTS}

We would like to thank Ms. Rosana Prisco for the statistical analyses. We regret to inform that our beloved colleague Sílvia de Campos Boldrini tragically passed away in June 2011. Her charisma, belief in the goodness of people, determination for the enhancement of science and teaching of anatomy were the biggest legacy she has left in our lives. This work was financially supported by the Fundacao de Amparo a Pesquisa do Estado de Sao Paulo (FAPESP No. 06/56045-9). Partial financial 
support was also obtained through a CAPES/CNPq scholarship.

RESUMO: A subnutrição ainda é uma condição importante na saúde pública por afetar principalmente crianças. O presente estudo tem o objetivo de avaliar os efeitos da subnutrição pré-natal e renutrição pós-natal no metabolismo de ratos jovens. Quarenta e cinco ratos Wistar machos originados de diferentes ninhadas foram utilizados. O grupo Nutrido $(\mathrm{N}, \mathrm{n}=15)$ e Subnutrido $(\mathrm{U}, \mathrm{n}=30)$ foram mantidos sob dieta protéica e hipoprotéica (20\% e 5\% de caseína, respectivamente) desde a fase intrauterina até o final do experimento. O grupo Renutrido (R) conteve 15 animais aleatoriamente selecionados do grupo U para consumir a dieta protéica a partir do dia 21 pós-natal (desmame). Todos os grupos foram mantidos até o dia 60. Os animais do grupo U desenvolveram pelos tardiamente, uniformemente escassos e sudorese intensa, fato não visto ao longo do experimento nos animais R e N. Os animais R obtiveram o maior ganho de peso, fração ingestão por peso e consumo de água por peso no período experimental, seguido pelo grupo N. O peso corporal final e a ingestão final de alimento ficaram decrescentes na ordem N-R-U, enquanto que para todos os outros parâmetros não houve diferença estatística entre o animal N e R. Comparativamente ao grupo N e R, o grupo U consumiu $90 \%$ e $81 \%$ a mais de alimento e água, respectivamente. A subnutrição proteica induziu disfunção metabólica nos animais U. A semelhança nos parâmetros experimentais entre o grupo $\mathrm{N}$ e R sugere que a correção precoce da alimentação foi eficaz no retorno das funções orgânicas dos animais R.

PALAVRAS-CHAVE: Subnutrição. Renutrição. Metabolismo. Nutrição. Ratos.

\section{REFERENCES}

ANTHONY, L. E.; EDOZIEN, J. C. Experimental protein and energy in the rat. The Journal of nutrition, Bethesda, v. 105, n. 6, p. 631-648, 1975.

BAPTISTA, J. S et al. Morphological characteristics of the rat thymus during perinatal protein deprivation and early refeeding: a qualitative and quantitative study. Journal of Morphological Sciences, Sao Paulo, v. 30, n. 1, p. 33-42, 2013.

BEDI, K. S. Effects of undernutrition during early life on granule cell numbers in the rat dentate gyrus. The Journal of Comparative Neurology, New York, v. 311, n. 3, p. 425-433, 1991.

http://dx.doi.org/10.1002/cne.903110311

BRETON, C. et al. Maternal prenatal undernutrition alters the response of POMC neurons to energy status variation in adult male rat offspring. American Journal of Physiology. Endocrinology and Metabolism, Bethesda, v. 296, n. 3, p. E462-472, 2009.

CASTELUCCI, P. et al. Effects of pre- and postnatal protein deprivation and postnatal refeeding on myenteric neurons of the rat large intestine: a quantitative morphological study. Cell and Tissue Research, Berlin, v. 310, n. 1, p. 1-7, 2002. http://dx.doi.org/10.1007/s00441-002-0615-y

COUPÉ, B. et al. The timing of "catch-up growth" affects metabolism and appetite regulation in male rats born with intrauterine growth restriction. American Journal of Physiology. Regulatory, Integrative and Comparative Physiology, Bethesda, v. 297, n. 3, p. R813-824, 2009.

http://dx.doi.org/10.1152/ajpregu.00201.2009

DESAI, M.; BABU, J.; ROSS, M. G. Programmed metabolic syndrome: prenatal undernutrition and postweaning overnutrition. American Journal of Physiology. Regulatory, Integrative and Comparative Physiology, Bethesda, v. 293, n. 6, p. R2306-2314, 2007. http://dx.doi.org/10.1152/ajpregu.00783.2006

DOMÍNGUEZ-GERPE, L.; REY-MÉNDEZ, M. Role of pre-T cells and chemoattractants on stress-associated thymus involution. Scandinavian Journal of Immunology, Bergen, v. 52, n. 5, p. 470-476, 2000.

http://dx.doi.org/10.1046/j.1365-3083.2000.00798.x 
GOMES, O. A. et al. Effects of pre- and postnatal protein deprivation and postnatal refeeding on myenteric neurons of the rat small intestine: a quantitative morphological study. Autonomic Neuroscience: Basic and Clinical, London, v. 126-127, p. 277-84, 2006. http://dx.doi.org/10.1016/j.autneu.2006.03.003

GREGGIO, F. M. et al. Effects of perinatal protein deprivation and recovery on esophageal myenteric plexus. World Journal of Gastroenterology, Dongsihuan Zhonglu, v. 16, n. 5, p. 563-70, 2010.

LIBERTI, E. A. et al. Effects of combined pre- and post-natal protein deprivation on the myenteric plexus of the esophagus of weanling rats: a histochemical, quantitative and ultrastructural study. World Journal of Gastroenterology, Dongsihuan Zhonglu, v. 13, n. 26, p. 3598-604, 2007. http://dx.doi.org/10.3748/wjg.v13.i26.3598

MONTE, C. Malnutrition: a secular challenge to child nutrition. Jornal de Pediatria, Rio de Janeiro, v. 76, n. 8, p. 285-97, 2000.

MONTEIRO, C. A. A dimensão da pobreza, da desnutrição e da fome no Brasil. Estudos Avançados, São Paulo, v. 17, n. 48, p. 7-20, 2003. http://dx.doi.org/10.1590/S0103-40142003000200002

MUGERWA, J. W. The lymphoreticular system in Kwashiorkor. The Journal of Pathology, Weinheim, v. 105, n. 2, p. 105-109, out. 1971. http://dx.doi.org/10.1002/path.1711050204

NAKAJIMA, K. et al. Malnutrition suppresses cell cycle progression of hematopoietic progenitor cells in mice via cyclin D1 down-regulation. Nutrition, Los Angeles, v. 30, n. 1, p. 82-89, 2014.

http://dx.doi.org/10.1016/j.nut.2013.05.029

NEUMANN, C. G.; GEWA, C.; BWIBO, N. O. Child nutrition in developing countries. Pediatric Annals, Thorofare, v. 33, n. 10, p. 658-674, 2004. http://dx.doi.org/10.3928/0090-4481-20041001-09

NUNES, M. L. et al. Effects of early malnutrition and nutritional rehabilitation in rats. Jornal de Pediatria, Rio de Janeiro, v. 78, n. 1, p. 39-44, 2002.

OLIVEIRA, F. DE et al. Morphological changes in distant muscle fibers following thermal injury in Wistar rats. Acta cirúrgica brasileira / Sociedade Brasileira para Desenvolvimento Pesquisa em Cirurgia, São Paulo, v. 25, n. 6, p. 525-528, 2010.

PIMSTONE, B. L. et al. Studies on growth hormone secretion in protein-calorie malnutrition. The American Journal of Clinical Nutrition, Bethesda, v. 21, n. 5, p. 482-487, 1968.

REEVES, P. G.; NIELSEN, F. H.; FAHEY, G. C. AIN-93 purified diets for laboratory rodents: final report of the American Institute of Nutrition ad hoc writing committee on the reformulation of the AIN-76A rodent diet. The Journal of Nutrition, Bethesda, v. 123, n. 11, p. 1939-1951, 1993.

ROMANI, S. DE A. M.; LIRA, P. I. C. DE. Fatores determinantes do crescimento infantil. Revista Brasileira de Saúde Materno Infantil, Recife, v. 4, n. 1, p. 15-23, 2004.

SAVINO, W. et al. The thymus is a common target in malnutrition and infection. The British Journal of Nutrition, Cambridge, v. 98 Suppl 1, p. S11-16, 2007. http://dx.doi.org/10.1017/s0007114507832880

VIAU, V. et al. Gender and puberty interact on the stress-induced activation of parvocellular neurosecretory neurons and corticotropin-releasing hormone messenger ribonucleic acid expression in the rat. Endocrinology, Washington, v. 146, n. 1, p. 137-146, 2005. http://dx.doi.org/10.1210/en.2004-0846

WATERLOW, J. C. Protein-energy malnutrition: the nature and extent of the problem. Clinical Nutrition, Edinburgh, v. 16 Suppl 1, p. 3-9, 1997. http://dx.doi.org/10.1016/S0261-5614(97)80043-X

WERNETTE, C. M.; WHITE, B. D.; ZIZZA, C. A. Signaling proteins that influence energy intake may affect unintentional weight loss in elderly persons. Journal of the American Dietetic Association, Philadelphia, v. 111, n. 6, p. 864-873, jun. 2011. http://dx.doi.org/10.1016/j.jada.2011.03.011 